\section{Policy Research Work
Competition Policy, \\ Developing Countries, \\ and the World Trade \\ Organization}

Bernard Hoekman

Peter Holmes wpsaall

2211
Developing countries have a great interest in pursuing active domestic competition policy but should do so independent of the World Trade Organization - which they should use to improve market access through further reduction in direct barriers to trade in goods and services.

The World Bank

Development Research Group

Trade

October 1999 


\section{Summary findings}

Hoekman and Holmes discuss developing country interests in including competition law disciplines in the World Trade Organization (WTO).

Developing countries have a great interest in pursuing active domestic competition policy, they conchde, but should do so independent of the WTO.

Given the mercantilist basis of multilateral trade negotiations, the WTO is less likely to be a powerful instrument for encouraging adoption of welfareenhancing competition rules than it is to be a forum for abolishing cross-border measures.

Developing countries should therefore give priority to using the WTO to improve market access - to further reduce direct barriers to trade in goods and services.

This paper - a product of Trade, Development Research Group - is part of a larger effort in the group to analyze issues that may be the subject of WTO negotiations. Copies of the paper are available free from the World Bank, $1818 \mathrm{H}$ Street NW, Washington, DC 20433. Please contact Lili Tabada, room MC3-333, telephone 202-473-6896, fax 202-522-1159, Internet address Itabada@worldbank.org. Policy Research Working Papers are also posted on the Web at http:// wbln0018.worldbank.org/research/workpapers.nsf/policyresearch?openform. The authors may be contacted at bhoekman @worldbank.org or p.holmes(asussex.ac.uk. October 1999. (25 pages)

The Policy Research Working Paper Series disseminates the findings of work in progress to encourage the exchange of ideas about development issues. An objective of the series is to get the findings out quickly, even if the presentations are less than fully polished. The papers carry the names of the authors and should be cited accordingly. The findings, interpretations, and conciusions expressed in this paper are entirely those of the authors. They do not necessarily represent the view of the World Bank, its Executive Directors, or the coumtries they represent. 


\title{
Competition Policy, Developing Countries and the WTO ${ }^{\star}$
}

\author{
Bernard Hoekman \\ World Bank and CEPR \\ and \\ Peter Holmes \\ University of Sussex and College of Europe, Bruges
}

JEL classification codes: F13; L40

Keywords: competition policy, trade negotiations, World Trade Organization, economic development

Correspondence: 1818 H St. NW, Washington DC 20433; tel: (1) 202473 1185; fax: 2025221159

* The views expressed in this paper are personal and should not be attributed to the World Bank. We are grateful to Jim De Melo, Carsten Fink, Peter Lloyd, Petros C. Mavroidis, Patrick Messerlin, Damien Neven, Marcelo Olarreaga, Alasdair Young, a referee and participants at the Fondazione Eni Enrico Mattei workshop Trade and Competition in the WTO and Beyond, Venice, Dec. 4-5, 1998 and a conference organized by the Trade and Industrial Policy Secretariat in Johannesburg in September 1998 for helpful comments and discussions. 



\section{Non-technical summary}

Competition policy has an important role to play in developing countries, both in promoting a competitive environment and in building and sustaining public support for a pro-competitive policy stance by the government. Liberal trade and investment policies are a key element of a good competition policy, and priority should be given eliminating barriers to trade and FDI. However, in many sectors of the economy the threat of foreign competition will remain limited, and there is need to apply competition law to ensure that firms do not behave collusively and that market power is not exploited. This can and should be done independently of the WTO-no international disciplines are needed.

There are a number of potential rationales for international cooperation in the area of competition law, notably where multi-jurisdictional mergers take place and where welfare-reducing export cartels cannot be disciplined because the jurisdictions most able to collect evidence have no incentive to do so. This does not imply an international agreement that could improve global welfare can easily be negotiated. Given the mercantilist basis of multilateral trade negotiations, the WTO is less likely to be a powerful instrument to encourage adoption of welfare-enhancing competition rules than it is as a forum for the abolition of border measures.

The problem is that the agenda is likely to be dominated by market access issues more than international antitrust. That is to say that the typical dispute is about the interests of major producers in export markets, and not about ensuring the adoption of competition law that is in the interests of the economy as a whole. To oversimplify, trade officials from exporting countries want to force competition officials in importing countries to assist in opening markets. From a bureaucratic politics point of view, this can give rise to a conflict between competition or anti-monopoly authorities worldwide and trade officials. The competition officials are afraid that their main objective of defending economic efficiency may be made subordinate to trade officials whose aim is to promote exports.

Independent decisions and actions are required on the part of developing countries to ensure that competition policies are implemented that foster a liberal trade and investment regime, and that action can be taken under competition law statutes to ensure that markets are contestable. Multilateral surveillance and scrutiny of domestic competition policy may help in this regard, as it will support domestic "transparency" activities that focus attention on the competitive conditions that prevail in the economy. If there is a move to negotiate on competition law at the WTO, the challenge for developed as well as developing countries is to pull off the same trick that lies at the heart of the GATT, namely harnessing the interests of competing producers to promote the adoption of policies that are welfare enhancing.

Clearly there is scope for bargaining outside the area of competition law. The fact that the competition agenda is being driven by market access considerations does not mean this is the only factor that could enter into play. Pressure for modifications in anti-dumping law and for commitments by OECD competition authorities to provide assistance to developing country competition authorities are examples of the type of quid pro quo that could be sought. Realism suggests, however, that the primary focus should be on the design of appropriate national policies. Developing countries should use the opportunities offered by the WTO to implement a pro-active, broad-based competition policy stance as this is in their own interest, while seeking all the leverage they can to increase the contestability of world markets. 



\title{
Competition Policy, Developing Countries and the WTO
}

\author{
Bernard Hoekman (World Bank) and Peter Holmes (Sussex University)
}

Competition law (antitrust in US parlance) is increasingly attracting the attention of trade policy officials in OECD countries, driven by domestic export interests who argue that anticompetitive practices impede their ability to sell goods and services in foreign markets. In 1996, the World Trade Organization (WTO) created a Working Group to investigate the relationship between trade and competition policies, and negotiations on this subject may be launched at some point. Views on whether competition law disciplines should be incorporated into the multilateral trading system vary widely in both the policy and academic communities. Despite an ever-expanding literature on the subject, the debate remains contentious; there is no emerging consensus regarding whether and how to address competition issues in the WTO. This is reflected in the first report issued by the Working Group in late 1998, which simply recommended that discussions in the group be continued (WTO 1998a).

In this paper we review the "state of the debate" from a developing country perspective. We start with some definitions of terms (section 1) and a discussion of the point of view of the main protagonists at the WTO: the EU, US, Japan and the newly industrialized countries of East Asia (section 2). We then consider the case for national competition legislation in developing countries (section 3 ) and their potential interests in multilateral disciplines in this area (section 4). The major options that may be pursued at the multilateral level are summarized in Section 5. Section 6 concludes.

Developing countries have a great interest in implementing an active domestic competition policy; indeed, in order to minimize the potential negative consequences of implementing some WTO Agreements, an appropriately worded competition law should be developed. This can and should be done independently of the WTO-no international disciplines are needed. However, there are a number of potential rationales for international cooperation in the area of competition law, notably where multi- 
jurisdictional mergers take place and where welfare-reducing export cartels cannot be disciplined because the jurisdictions most able to collect evidence have no incentive to do so. This does not imply an international agreement that could improve global welfare can easily be negotiated. Given the mercantilist basis of multilateral trade negotiations, the WTO is less likely to be a powerful instrument to encourage adoption of welfare-enhancing competition rules than it is as a forum for the abolition of border measures. We conclude that priority should be given to pursuit of the traditional market access focus of the WTO-further reduction in direct barriers to trade in goods and services. In our view this would have the greatest immediate beneficial impact on global welfare, although we are not arguing, as some have done, that external trade liberalization is by itself sufficient to curb transnational anti-competitive behavior.

\section{Defining Terms}

National competition law can be defined as the set of rules and disciplines maintained by governments relating either to agreements between firms that restrict competition or to the abuse of a dominant position (including attempts to create a dominant position through merger). A major objective of competition law in most jurisdictions is efficient resource allocation, and thereby the maximization of national welfare, by ensuring that the competitive process is not distorted or impeded through the abuse of dominant positions (either through prohibition or through regulation) or competition-restricting agreements between competitors that are detrimental to social welfare. Many jurisdictions recognize that specific agreements between firms that may reduce competition can be efficiency enhancing, and make allowance for such agreements. Countries vary in the emphasis that is placed on efficiency-many also include social objectives and "fairness" considerations in their legislation. 1

\footnotetext{
'See Richardson (1998) on the objectives of competition law.
} 
Competition policy has a much broader domain. It comprises the set of measures and instruments used by governments that determine the "conditions of competition" that reign on their markets. Antitrust or competition law is a component of competition policy. Other components can include actions to privatize state-owned enterprises, deregulate activities, cut firm-specific subsidy programs, and reduce the extent of policies that discriminate against foreign products or producers. Often the competition policy stance of a government may be determined in part by the international treaties it is a party to, including e.g., regional integration agreements. A key distinction between competition law and competition policy is that the latter pertains to both private and government actions, whereas antitrust rules pertain to the behavior of private entities (firms).

Many dimensions of competition policy are already on the WTO agenda-e.g., trade policy, subsidies, intellectual property protection, market access in services. The focus of the debate in the WTO is therefore on whether there should be specific rules pertaining to national competition law and its enforcement.

\section{Perspectives of High-Income Countries}

Support for international disciplines in the area of competition law was originally stimulated by US perceptions that international cartels and the absence or non-enforcement of national competition law impeded the ability of US firms to contest markets. The US has been arguing for many years that Japanese corporate groups (Keiretsu) undermine market access for foreign suppliers by buying predominantly from each other and retaining close vertical linkages between manufacturers, wholesalers and retailers. In the 1940s at the time of the negotiations to establish an International Trade Organization (ITO), the US supported inclusion of a chapter dealing with restrictive business practices, reflecting its opposition to German cartels and Japanese zaibatsu. More recently the EU has been in the forefront, arguing that all WTO members must adopt and enforce competition laws. The US appears to be of the view that it would be preferable to act unilaterally and/or pursue bilateral cooperation (Klein, 1998; 
Janow, 1998). US authorities acknowledge there is a need for international cooperation. For example, Assistant Attorney-General Joel Klein has argued that the inability to share confidential information is a problem: "we must continue to bolster competition laws and enforcement efforts in nations around the world, and to facilitate the kind of exchanges of confidential information that are essential to coordinated enforcement activities" (Klein 1995). But the US are not willing to allow their own rules to be subordinated to an international régime of any kind. Its competition authorities do not want to change their laws in any way or to find themselves fighting market access battles, although US law has begun to provide for this in certain circumstances. ${ }^{2}$

US and EU proponents of international competition rules have a predominantly "market access" driven agenda. Non-existent or poorly enforced competition laws are argued to hinder access for exporters by allowing domestic firms to foreclose or greatly increase the cost of entry. Other high-income countries argue that the main issue from a WTO market access perspective is not competition law and policy but the use of traditional instruments of contingent protection such as antidumping to restrict access to markets. This is the position of Japan and other Asian WTO members, most vocally Hong Kong. Smaller countries, especially developing ones, have also been concerned about possible anticompetitive behavior by large (dominant) multinationals. Both the EU and the US are large economic entities, with domestic competition authorities that are well-equipped to address anticompetitive behavior that has detrimental consequences for consumers located in their jurisdiction. Developing countries will have less capacity to discipline possible anticompetitive abuses by foreign multinational firms on their markets. Perhaps the most obvious example are export cartels designed to exploit market power on foreign markets. Such cartels benefit home countries if any detrimental effect on home consumers is small and more than offset by the gains to producers associated with their ability to raise prices on foreign markets. The latter will be to the detriment of foreign welfare if the costs to consumers outweigh the

2 See Fox (1997) and Mavroidis and Neven (1998). 
increase in domestic producer surplus. Developing countries therefore may stand to gain from an international agreement that outlaws such welfare-reducing cartels, ${ }^{3}$ provides for their interests to be taken into account when large mergers are considered, and provides mechanisms to enforce multilateral disciplines:

This brief introduction illustrates that there may be significant variation in the interests of different OECD countries regarding the type of competition disciplines that would be considered beneficial (acceptable). The main interest of the EU and US is to use competition policy disciplines as an export-promoting device and to reduce the scope for conflict in the approval of mergers between large firms; they are less interested in subjecting the behavior of their firms in foreign markets to international disciplines that will benefit foreign consumers. Market access is also of interest to small countries, but these may be concerned as well with being able to invoke assistance in disciplining anticompetitive behavior of firms located in foreign jurisdictions.

\section{Market Access and Vertical Restraints}

The type of market access concerns that arise were recently illustrated in the dispute between Kodak and Fuji that was brought to the WTO as a so-called "non-violation" complaint under Article XXIII of the GATT. This allows members to challenge government measures that "nullify or impair" trade liberalization commitments even though the measures themselves are not subject to WTO rules (Hoekman and Mavroidis, 1994). The US alleged that informal administrative guidance, industrial policy tools applied by Japanese firms themselves, and guidelines on what constituted fair and unfair competition allegedly deprived Kodak of marketing tools that were of special importance to it as an outsider. Most directly on the competition front, the US claimed that because Fuji controlled the distribution system, this allowed it to exclude Kodak from access to film wholesaling networks, obliging

3 Of course, some small nations that are the home country of large multinational firms may benefit from the ability of such firms to exercise market power in foreign markets. 
it to sell directly to retailers, a much less efficient method of market penetration. The key allegation was thus of an anti-competitive vertical relationship between Fuji and its primary distributors. Japan responded that the control by Fuji of wholesale networks was irrelevant since most of the retailers they served also bought imported film and that Kodak's own distribution system amounted to the creation of a wholesale system of its own, the exclusion from the Fuji system, such as it was, therefore being irrelevant.

The WTO dispute panel agreed to treat all the "measures" attacked by the US, including decisions of the Japan Fair Trade Commission regarding the absence of anti-competitive practices by Fuji, as possible grounds for complaint as they could have affected trade. On examining the facts, it concluded there was no impairment of US market access rights. The panel investigated claims that restrictions on certain forms of marketing strategy affected importers disproportionately and concluded that they did not. They did not see anything in Japanese distribution structures that excluded foreigners as a result public policy, even on a wide interpretation of this term. In particular they concluded that: "single-brand wholesale distribution is the common market structure--indeed the norm-in most major national film markets, including the US market. While the United States responds that the US market structure was the result of private and not governmental actions, it is unclear why the same economic forces acting in the United States would not also exist in Japan."(WTO, 1998b, p. 421)

Kodak-Fuji revolved around one of the most sensitive but also most obscure areas of competition and trade policy: exclusive or selective "vertical" arrangements between upstream and downstream sellers. These are typically arrangements where a producer gives sole rights to one wholesaler or retailer in an area, and/or imposes the condition that anyone handling their goods (or services) must not act for any other firm. Although the US systematically accuses Japanese "Keiretsu" groups of using control of the wholesale sector to exclude foreign goods, there is no agreement among lawyers or economists about whether and when such "vertical" arrangements are ever genuinely anti-competitive. This is the key question, not whether firms from a particular country have a market share they are unhappy with. 
Unfortunately it is often difficult to answer; identifying producer interests is much easier. As a result the scope for conflict is significant, as firms and governments put zero weight on the welfare or efficiency dimensions of a given situation existing in a foreign country.

Another example concerns the treatment of parallel imports, i.e. imports of branded goods bought in markets where they are cheaper to avoid high price official marketing channels. The EU has criticized Japan for allowing parallel imports of branded European goods into Japan, allegedly undermining expensive distribution networks foreign firms have had to set up. The US Trade Representative has protested to New Zealand over a law that is based on the principle of international exhaustion and bans restrictions on parallel imports (Financial Times May 26 1998). The EU, as does the US, applies a policy of "national" exhaustion (regional in the case of the EU), under which traders have the right to move goods across internal borders. Distribution arrangements such as exclusive licensing which segment the internal market are not prohibited, but third parties have the right to move goods across internal borders after the initial sale of the good has occurred. However, with respect to third markets, firms may prevent parallel imports or reimports that cross the external frontier. European Commissioner Mario Monti has recently announced a re-think of this policy (The Economist, February 27, 1999, p. 72). The treatment of parallel imports could become an important focal point for future WTO discussions on competition law, with small countries having an interest in adopting international exhaustion and allowing parallel imports and large countries (more generally, those with important producers of branded goods and services) having an interest in getting all countries to apply the principle of national exhaustion (Cottier, 1998).

The Kodak-Fuji case confirmed that government measures, including actions directly or indirectly linked to competition policy, that foster anti-competitive behavior and exclude rivals can in principle be challenged at the WTO. However, it also illustrated that the "non-violation" process is an inherently limited instrument through which to attack the (non-)application of national competition laws. WTO panels are ill-equipped to investigate competition issues; are limited in the extent to which they can engage in a process of "discovery"; and even if they have the will to be pro-active, there are no effective 
remedies available (as by definition there is no "violation" of a WTO rule). The main value of bringing non-violation cases is that it provides a forum in which the facts of the matter can be determined and assessed-it is a valuable transparency device (Hoekman and Mavroidis, 1994). Time will tell if other countries will bring similar cases to the WTO.

\section{Mergers and Acquisitions with International Spillovers}

Another potential source of conflict concerns control of mergers. There are basically two somewhat overlapping sets of interests. Competition authorities want effective leverage over mergers that may have cross border effects, while firms want to minimize the number of agencies they are accountable to. In principle, mergers between firms that will have a very high combined market share in markets where they are not domiciled can be a serious source of concern for a competition authority. Many global mergers and alliances have occurred that have been approved without disputes by the major affected jurisdictions. But in the recent Boeing-McDonnell Douglas (MDD) case the US and EU took different views and only a last minute compromise prevented a serious conflict from erupting. The Boeing-MDD merger involved two US-based firms whose combined sales in the EU were big enough for the EU Commission to claim

right of scrutiny (something the US authorities did not contest). What was interesting about the case was that the EU was concerned that certain of Boeing's long-term sole-sourcing contractual arrangements with airlines risked permanently excluding Airbus if they were not challenged. Thus, the concern was not that the merger would result in higher prices for aircraft buyers (Mavroidis and Neven, 1998). The issue was to protect the interests of the only EU competitor of Boeing-MDD. The EU refused to approve the merger unless Boeing agreed to not to enforce the sole-sourcing contracts, which in the end it accepted.

The contested arrangements were unrelated to the merger as they involved Boeing and some of its customers - if they were bad for the EU, they were bad independent of the merger. This raises the question why objections were not raised earlier by the EU (or by MDD in the pre-merger period). 
This case illustrates that interests of different jurisdictions can diverge considerably in merger cases. It suggests there may be value to adoption of rules to foster transparency, e.g., harmonization of notification procedures. Less clear is how to address the problem of a number of national authorities making mutually exclusive demands on a merging entity. For an international agreement to have prevented a similar dispute or the eventual negotiated outcome, it would have to impose clear standards for examination and review of mergers. The EU and the US already cooperate on antitrust matters under the auspices of a bilateral agreement that includes positive comity language. This was not sufficient to prevent the dispute. One can question whether international rules could be devised that would be effective in requiring any one jurisdiction to back off.

Summing up, efforts to put competition-related issues on the WTO agenda are largely driven by classic producer interests in major OECD countries, with governments pursuing a traditional "exportpromotion" objective. The primary concern is not welfare or efficiency-the major focus of many national antitrust regimes. Hence a basic tension exists that leads to the following question: how might an international agreement on competition policy that is geared towards dealing with market access pressures and will be driven by a desire to defend national producer interests help to enhance welfare? The answer in the case of the trade policy instruments that are at the heart of the GATT is well knownthe pursuit of mercantilist objectives by trade negotiators leads to an outcome that is welfare improving because it helps governments to overcome the opposition of politically-powerful interest groups that are able to block unilateral liberalization attempts. The key question in the case of competition policy is whether a similar dynamic can be set into motion. We return to this below.

\section{Competition Law and Developing Countries}

Developing countries have not been at the center of the debate on trade and competition in the WTO. Many do not have competition laws; those that do, often have limited implementation ability. If competition law moves on to the WTO agenda, an important question for developing country 
policymakers is what this will imply for their ability to adopt antitrust and competition policies that are in the national interest. This in turn requires a view on what is and what is not desirable.

From an economic perspective, policy should aim at safeguarding the competitive process so that firms are able to compete away any excess profits that may exist at any point in time. Trade economists believe that a liberal trade policy stance is the cheapest and most effective competition policy instrument available to a government. Competition from imports is a very important source of market discipline for firms. This is the case in particular for countries with highly concentrated industrial structures inherited from the past, as the resulting monopoly rents may be a major drag on the economy. As the magnitude of trade restrictions in most developing countries significantly exceeds those that are applied by high income nations, trade economists tend to argue that priority should continue to be given to reducing traditional trade barriers. This prescription is strengthened if account is taken of the fact that many sectors are not tradable-here priority should be given to allowing entry by foreign multinationals, as FDI will be a primary source of market discipline. At the same time, as UNCTAD (1997) points out, it should be clearly signaled to firms that inward investment that is motivated by the pursuit and eventual abuse of a dominant position will be dealt with by competition law.

Developing countries are mostly pricetakers on world markets; outside of certain natural resources, their firms generally have no market power. Even if they do, it is difficult to design and implement policies that will shift the terms of trade in a country's favor. 4 The international experience indicates that reductions in trade barriers reduce price-cost mark-ups, especially among large firms. Plant sizes tend to decline, but the effect on scale efficiency is generally modest because most of the adjustment in total domestic output comes from large firms that were operating on the flat portion of their average cost curves (Roberts and Tybout, 1997). Trade acts as a conduit for knowledge transmission, and protection chokes off a necessary ingredient. Similarly, access to foreign intermediate and capital goods is important

\footnotetext{
${ }^{4}$ See, for example, the analysis by De Melo, Olarreaga and Takacs (1999) on the policies used by Madagascar in an attempt to exploit it's large share of the global vanilla market.
} 
to final goods producers. There is extensive evidence that exporting to knowledgeable buyers in highincome countries has helped developing country firms acquire global best practices: buyers transmit blueprints and teach quality control; help organize the shop floor; transmit information about better inputs available abroad. Technology also transfers through imports of intermediates, capital-goods, and through de-engineering of imports.

Although a free trade stance-defined to include the freedom for foreign firms to establish (invest)-greatly reduces the scope for anticompetitive practices to be sustainable, it does not imply that the need for competition law disappears. Competition may be limited to local markets-e.g., retail distribution-and certain products may be produced by (natural) monopolies, by firms with global market power, or by firms where natural or 'unnatural' (government-made) barriers to entry restrict contestability. Recent research has confirmed an old insight that free entry into an industry depends on there being no scope for an existing dominant firm to "punish" a new entrant by cutting prices when it is attacked. This will act as a serious deterrent to new entry unless there are no barriers to "exit". That is to say, if a new firm which finds a market unprofitable can leave it without losing its initial investment, then the market will really be effectively open, but if a new entrant risks being stranded in an unprofitable activity it will fear entry. ${ }^{5}$

Developing countries should seek to ensure that their competition laws and related regulations aim at safeguarding the competitive process. Where institutional enforcement capacity is limited, it is desirable for political structures to do all they can to make conditions as favorable as possible for pro-competitive behavior, which includes sustaining free trade and avoiding the creation of monopolies through perverse regulation or by ill-conceived privatization. This has led many specialists to recommend that developing countries pursue a broad-based competition policy-defined to encompass all actions governments may take to promote competition, including trade liberalization, measures to facilitate

\footnotetext{
${ }^{5}$ Much depends here on the specifics of the technologies and cost structures. In the absence of sunk costs, there may be excessive entry. Barriers to entry may therefore be welfare increasing.
} 
domestic entry into industry and services, de-monopolization of sectors, and imposition of hard budget constraints on public enterprises. Well-managed privatization and encouragement of foreign direct investment are additional important dimensions of competition policy. The key principle underlying an active competition policy stance is to rely on market forces to determine the allocation of productive resources, subject to the constraint of ensuring that social equity objectives are realized as efficiently as possibls, and that mechanisms exist through which attempts to create monopolies and exploitation of market power can be addressed.

Competition policy, as opposed to competition law, should have as a major priority the creation of pre-conditions likely to assure the effective functioning of competition, rather than seeking to punish violations of the rules. This leads many writers to suggest that competition authorities play a general "advocacy" role within government, for example trying to oppose trade or other policy measures that will limit or distort competition, or taking an active part in debates over privatization to ensure that this does not create conditions for monopolistic abuse (Boner, 1991; Boner and Krueger, 1995; Kemani and Dutz, 1995). Of particular importance in this connection is to ensure that legislation and government regulation is consistent. This is a dimension of competition policy that is often neglected but can be vital in enabling a country to maximize the benefits of trade liberalization and WTO membership. One often mentioned example is contingent protection, where the application of competition criteria can help ensure that intervention does not become excessively costly to the economy (Hoekman and Mavroidis, 1996). Another example is the policy stance taken towards exhaustion of IPRs mentioned earlier, including the legal status of exclusive geographical distribution arrangements and parallel imports. As far as competition law narrowly defined is concerned, care should be taken that the legislation is not captured or abused by producer interests. This is a possibility that should be taken seriously at the design or drafting stage. The greater the number of objectives or constraints that a competition authority is required to take into consideration, the higher the likelihood that the focus of enforcement efforts will not center primarily on safeguarding the competitive process. 
Parallel imports and exhaustion of intellectual property rights

Before the Uruguay Round, the US periodically threatened countries with trade penalties under Section 301 of its trade legislation if they did not enforce patent and copyright rules, even where the countries in question had no legal obligation to do so, not having signed the Paris and Berne Conventions on the subject. The Uruguay Round TRIPs agreement obliged all WTO members to enforce intellectual property rights, though with transition periods for developing countries. Whether developing countries will gain from stronger protection of IPRs is a matter of debate. Those in favor argue that dynamic benefits resulting from greater incentives for innovation, both at home and abroad, and for owners of knowledge to license technologies will more than offset any static losses. On balance the short-run impact of the TRIPs régime is likely to cause a transfer of income from poor to rich countries, with at best marginal impacts on economic efficiency (Primo Braga, 1996). The scale of the transfer very much depends on the market structures assumed to exist in the patentable products and the closeness of availability of substitutes.

The TRIPS agreement explicitly authorized the use of competition policy measures against abuses of IPRs. As right holders will frequently use their IPRs to segment markets, developing countries may therefore have a strong interest in applying an international exhaustion rule similar that that applied within the EU by EC competition policy. This would imply that domestic buyers could purchase patented and branded products wherever they find the most favorable prices. This is fully compatible with the TRIPs agreement: Article 40 allows measures to control abuse of IPRs through the application of competition law (Cottier and Meitinger, 1998). Thus, even though both the EU and the US are active proponents of a national and regional approach in this area, respectively, there is no presumption that other countries should also follow this route.

The economics of this issue are complex. Many experts argue that as long as a producer faces competition from other brands exclusive arrangements do not matter. But in many developing countries 
the major brands may all be in the hands of one entity or a de facto cartel. In the absence of competition law enforcement, national exhaustion and legally enforceable exclusive distributor arrangements can then have a major detrimental impact on welfare. ${ }^{6}$ Even if there is vigorous inter-brand competition, whether to adopt international exhaustion should be a matter for national authorities to decide independently. The implementation of the TRIPs agreement affords an opportunity to consider the intimate linkages between intellectual property protection, trade liberalization, and competition policy (Maskus, 1998). Hong Kong's recent experience is illustrative. Enforcement of TRIPs-type protection of IPRs led to the exclusion of gray market parallel imports and allegations of abuse of a dominant position, which the Hong Kong government has generally not worried about given its free trade stance. The Director-General of the Department responsible for enforcing the IP law recognizes that the absence of a competition law creates potential problems, but notes that his job is to protect the interests of rights holders; "someone else must protect the others" (Financial Times, Jan 8., 1999).

To recapitulate, developing countries have an interest in adopting strong competition policies, the main pillar of which should be a liberal trade and FDI policy stance. Competition law is required to ensure markets are contestable, especially in nontradable sectors. It also has a role to play in controlling anticompetitive practices, which as Adam Smith already noted over two centuries ago, businessmen will always have an incentive to pursue. Antitrust legislation may also be required to maximize the benefits (or minimize the costs) of certain WTO agreements, the TRIPs agreement being one example, antidumping being another (see below). That said, competition law is not a panacea. Enforcement is neither costless nor simple, and can impose a great deal of uncertainty on firms if it is not clearly defined

6 An anecdote is illustrative. Lebanon has an exclusive distribution law that gives agents the right to request Customs to block entry of "nonauthorized" goods. On a trip in Germany a businessman buys a batch of second-hand dentist chairs made by Siemens from a university, which had used them for training purposes. On import into Lebanon, the shipment was blocked because the Siemens agent had not approved it. In the end the businessman was obliged to pay the agent a large fee and was forced to pay customs duty on the chairs on the basis of the value of new chairs, in effect wiping out his anticipated profit. 
and enforced consistently. This is an important reason why liberal trade and FDI (establishment) policies should be a primary pillar of a government's competition policy stance.

\section{International Agreement: Developing Country Interests}

While a vigorous competition policy will be beneficial for developing countries, this can be implemented unilaterally. What is the rationale for a multilateral agreement? For an international agreement to be beneficial, it must either offset an externality imposed by policies of other countries or help governments to overcome domestic political economy constraints that impede the adoption of welfare enhancing policy changes. The market access and merger control issues that dominate the agenda of major OECD countries are largely irrelevant for developing countries. Insofar as there are market access impediments resulting from anticompetitive behavior by incumbent firms, this can and should be dealt with by domestic competition authorities. Of course, in many countries institutional weaknesses may impede this, but that is a matter for technical and financial assistance that will not be solved by the adoption of international disciplines.

The merger issue is clearly of interest to developing countries who may suffer from the increased market power and reduction in competition that results from a merger of two or more "global" firms. They would benefit from rules requiring home country competition authorities to take the interests of third parties into account. This also applied to the more general potential problem for developing countries of being confronted with export cartels and analogous arrangements that reduce national welfare (the sum of consumer and producer surplus). This can be a major externality-related rationale for an international agreement on competition law. An agreement that would make export cartels illegal would likely be beneficial for developing nations, but may also be quite difficult to achieve. A precondition will be to define and agree on what is and what is not acceptable. Even for importing countries it is not necessarily the case that restrictive practices are detrimental to national welfare. The fact that it proved impossible to agree to ban export cartels in the OECD suggests agreement may be 
difficult to obtain (OECD, 1998). For large OECD countries, any agreement to make binding commitments to follow a positive comity rule in mergers (let alone agree on common standards of review) and to prohibit export cartels (or even to agree to provide information) will imply costs insofar as the practices concerned do not have a detrimental effect on home country welfare. They can therefore be expected to demand a significant quid pro quo of developing countries, one that may go beyond a general willingness to adopt and enforce competition legislation.

The political economy argument in favor of international competition disciplines is that external disciplines might prove helpful to overcome domestic opposition to the implementation of procompetitive policies. As noted previously, the foundation of the GATT and the WTO is that in the pursuit of a market access agenda the national welfare is promoted. National antitrust has a very different focus from national trade policy in that the emphasis is (should be) on welfare and the competitive process. This implies that the economic rationale for putting it on the WTO agenda is much weaker than for trade policy-national authorities should already be engaged in combating anti-competitive business practices. The pursuit of a market access agenda may result in outcomes that are detrimental from a welfare point of view (the latter possibility is a major reason some competition authorities are leery of putting antitrust on the WTO agenda, see e.g., Marsden (1997)). For the WTO dynamic to "work" one must start from the presumption that competition law and policy in developing countries has been or will be captured by domestic producer lobbies, and therefore does not focus on welfare maximization. If so, and this may indeed be the case in some cases, there would be a rationale for pursuing international competition disciplines in the WTO. The problem remains, however, that the WTO process is driven by export interests (market access), not national welfare considerations, and there is no assurance that the rules that will proposed or agreed will be welfare enhancing. Increasing access to markets may have this effect, but there is no presumption that this will always be the result, especially in contexts where firms are actively seeking to create and defend rents. Doubts can therefore be expressed regarding the ability of a WTO- 
based process to play as constructive a role in the area of competition law as it does in the area of trade policy.

\section{Assessing the Options}

Various criteria can be used to evaluate the desirability of alternative options for a WTO agreement in the area of competition law. From an economic perspective the key criterion is the likely impact on national welfare (economic efficiency) of WTO members. An attempt to identify the major options is made in Table 1 , with a + sign indicating a positive impact on welfare, a - sign a negative impact, and a 0 indicating no impact. Not surprisingly, in most cases a range of outcomes is possible. Space constraints prohibit an extensive discussion of the various options-see, e.g., EU $(1995,1996)$, Scherer (1994), Hoekman and Mavroidis (1995), Hindley (1996), Graham and Richardson (1997), Hoekman (1997), WTO (1997), Lloyd (1998), and Richardson (1998).

Table 1: Assessing the Options

\begin{tabular}{lc}
\hline Option & $\begin{array}{c}\text { National } \\
\text { welfare }\end{array}$ \\
\hline 1. Minimum substantive standards of antitrust law & $+1-$ \\
2. Expand the scope to bring nonviolation complaints & $+1-$ \\
3. Introduce antitrust criteria in antidumping & + \\
4. Give a greater transparency and "discovery" role to the WTO & + \\
5. Prohibit export "cartels" & $+1-$ \\
6. Adopt procedural and due process norms & +10
\end{tabular}

Note: + indicates positive impact, - a negative impact, and 0 no impact. More than one symbol indicates a range of outcomes is possible.

Harmonization of substantive law is in our view not desirable, and not enforceable in any event without a supra-national body. Most of the conflicts among OECD countries concern vertical restrictions, and there is no agreement if and when these are detrimental. The Chicago School of 
economists would hold that vertical restraints can almost never be harmful. Others argue that vertical restraints can exacerbate other market imperfections especially with asymmetric information. US courts therefore use a rule of reason approach, as the costs and benefits must be assessed on a case-by-case basis. Given the absence of a consensus, we are doubtful about any substantive international régime forcing the acceptance of one set of rules rather than another. And, as pointed out by many scholars, even if identical language were to be adopted in different jurisdictions, interpretations and decisions could easily differ depending on the weights put on various factors by national authorities (Fox, 1998).

Use of nonviolation dispute settlement might be facilitated by seeking agreement that nonenforcement of national antitrust law is a government "measure" and weakening the requirement that the measure was not "reasonably" foreseeable at the time the trade concessions were negotiated (Hindley, 1996). While this may expand the willingness to invoke this procedure, a problem that remains is that the remedies that may be suggested by a WTO panel cannot affect the national application of antitrust lawat best a complainant country will be offered compensation. This is unlikely to satisfy the firm that brought the complaint and thus to defuse conflicts.

The likelihood of disciplining antidumping through the introduction of competition law criteria - an often proposed option in the literature (e.g., Hoekman and Mavroidis, 1996)-is not high, to say the least, even though it would be welfare-improving. There are powerful lobbies that support the maintenance of antidumping. Moreover it is clear that the aim of anti-dumping is not the same as that of competition policy: one protects domestic firms (competitors), the other protects the competitive process. Recent free trade agreements illustrate the strength of the antidumping lobbies. The instrument continues to apply in NAFTA. Association Agreements involving the EU as a partner reveal that a commitment to apply common disciplines in areas such as antitrust, state aids, and state monopolies, and to adopt the whole of the EU's internal market rules is necessary to induce the EU to abolish the reach of antidumping on intra-regional trade. This was achieved in the case of the European Economic Area agreement, but not 
yet in any other. Disciplining antidumping is an issue for national constituencies to deal with; a necessary first step is to recognize that antidumping is straightforward protection (Finger, 1993).

Strengthening the WTO's transparency mandate to include information on the competition policy stance applied by governments could be beneficial. More data on the economic effects of government policies would be useful to affected domestic groups; it would also provide incentives for the establishment of domestic counterpart institutions. The latter is particularly important for developing countries. Domestic "transparency institutions" and competition agencies have long been promoted by trade policy and competition analysts who argue that public information on the costs and benefits of government policies is required in order to countervail rent-seeking activities (see e.g., Finger, 1982; Boner and Krueger, 1995). There are nontrivial issues that arise from a multilateral surveillance perspective. Competition enforcement is an ex post endeavor, and the "state of competition" is inherently difficult if not impossible to "quantify"--there are no tariff equivalents to be calculated. Nonetheless, basic cross-country data on entry and exit (turnover), the number of firms in a market and their size distribution, import penetration, the share of FDI in total assets by industry, etc. can provide useful indicators of the state of competition and trends over time, and may be helpful in identifying possible "outliers" (Djankov and Hoekman, 1998).

Developing countries may benefit from export cartels involving their firms, and these benefits may outweigh the costs associated with imports controlled by foreign export cartels. Whether or not a country will gain from a ban on export cartels depends on the balance between its ability to exploit market power on world markets by restricting supply and the extent to which it is confronted with such behavior on the part of other countries. On balance, it seems more likely that developing countries will confront the second situation more frequently, and may not have the ability to address such practices through national enforcement of competition law. Whether much progress can be made to ban export cartels is open to question, however. The US in 1997 proposed a voluntary agreement in the context of the OECD that would commit members to prosecute "hard-core cartels" that operate across more than 
one market to raise prices or restrict sales. The suggested agreement would do no more than "recommend" that countries "should" enforce their existing laws more strongly. It would tolerate any arrangements currently lawful, and thus would not address export cartels based in one country selling to others, or importer cartels that keep out foreign goods.

Finally, an agreement that imposes "procedural" norms for the implementation and enforcement of competition laws (agreement to adopt a competition law; notification and transparency provisions, "due process", legal assistance and procedural cooperation; adoption of the principle of positive comity) could also be beneficial. Although many developing countries have antitrust legislation, and many more are considering its introduction, enforcement may be uncertain or inconsistent. Procedural cooperation would also allow authorities in developing countries to request the assistance of counterparts in OECD countries and to consider their interests in the application of competition law. In the case of conflicts, the WTO could provide a mechanism for consultations and the exchange of information. 7

Summing up, any agreement on international competition policy that goes beyond general procedural cooperation and introduction of transparency mechanisms is likely to have be plurilateral, at least initially. The divergence in interests between WTO members is large, and commitments to undertake any significant harmonization of substantive norms (such as banning export cartels, the treatment of mergers, policy towards parallel imports, etc.) can be expected to require substantial crossissue linkages. The terms of any feasible deal are impossible to predict. But any deal involving a commitment by developing countries to adopt substantive competition rules would have to be accompanied by significant concessions from the demandeurs that they are not willing or able to offer on a general basis.

$7 \quad$ Sere Fox (1998), Graham and Richardson (1997) and Richardson (1998) for discussions of options revolving around procedural cooperation and transparency. 
Competition policy has an important role to play in developing countries, both in promoting a competitive environment and in building and sustaining public support for a pro-competitive policy stance by the government. Liberal trade and investment policies are of vital importance in fostering competition, and priority should be given eliminating barriers to trade and FDI. However, in many sectors of the economy the threat of foreign competition will remain limited, and there is need to apply competition law to ensure that firms do not behave collusively and that market power is not exploited. Competition legislation is also required to allow countries to combat the possible anticompetitive implications of certain WTO agreements. TRIPs is one example, antidumping another. While a multilateral agreement to apply competition criteria and tests in the antidumping context will be opposed by major users, nothing constrains a nation from doing this on a unilateral basis.

The desirability of increased voluntary international cooperation in the area of competition law, which may be bilateral (e.g. EU-US) or plurilateral, must be distinguished from attempts to agree on binding multilateral disciplines. In principle, a commitment to more thorough policing by industrial countries of their own exporters, of global strategic alliances (e.g. in telecoms), and import-competing industries' use of instruments of contingent protection could have very general benefits for developing countries. However, in the present environment there are unlikely to be substantial benefits for developing countries from any feasible multilateral agreement on competition law. The problem is that the agenda is likely to be dominated by market access issues more than international antitrust. That is to say that the typical dispute is about the interests of major producers in export markets, and not about ensuring the adoption of competition law that is in the interests of the economy as a whole. To oversimplify, trade officials from exporting countries want to force competition officials in importing countries to assist in opening markets. From a bureaucratic politics point of view, this can give rise to a conflict between competition or anti-monopoly authorities worldwide and trade officials. The competition officials are afraid that their 
main objective of defending economic efficiency may be made subordinate to trade officials whose aim is to promote exports.

Independent decisions and actions are required on the part of developing countries to ensure that competition policies are implemented that foster a liberal trade and investment regime, and that action can be taken under competition law statutes to ensure that markets are contestable. Multilateral surveillance and scrutiny of domestic competition policy may help in this regard, as it will support domestic "transparency" activities that focus attention on the competitive conditions that prevail in the economy. If there is a move to negotiate on competition law at the WTO, the challenge for developed as well as developing countries is to pull off the same trick that lies at the heart of the GATT, namely harnessing the interests of competing producers to promote the adoption of policies that are welfare enhancing. How can the desire of firms for market access be made compatible with the need to ensure the markets they enter become and remain competitive, without imposing unreasonable administrative burdens?

The EU wants to oblige all WTO members to have some form of competition law. It is inconceivable that there could be agreement on precise formulations: there would surely be enough interests to veto a precise set of vertical rules for example. Developing countries should use the occasion of the EU proposal to put their interests on the table, recognizing that thequid pro quo they can expect will depend importantly on what they are willing to offer. Clearly there is scope for bargaining outside the area of competition law. The fact that the competition agenda is being driven by market access considerations does not mean this is the only factor that could enter into play. Pressure for modifications in anti-dumping law and for commitments by OECD competition authorities to provide assistance to developing country competition authorities are examples of the type of quid pro quo that could be sought. Realism suggests, however, that the primary focus should be on the design of appropriate national policies. Developing countries should use the opportunities offered by the WTO to implement a pro-active, broad-based competition policy stance as this is in their own interest, while seeking all the leverage they can to increase the contestability of world markets. 


\section{References}

Boner, Roger. 1995. "Competition Policy and Institutions in Reforming Economies," in C. Fritschak (ed.) Regulatory Policies and Reform: A Comparative Analysis. Washington D.C.: The World Bank.

Boner, Roger and Reinald Krueger. 1991. The Basics of Antitrust Policy: A Review of Ten Nations and the European Communities. Washington D.C.: World Bank Technical Working Paper No. 160.

Cottier, Thomas. 1998. "The WTO System and Exhaustion of Rights," presented at the Committee on International Trade Law conference on Exhaustion of Intellectual Property Rights and Parallel Importation in World Trade, November 6-7, Geneva.

Cottier, Thomas and Ingo Meitinger. 1998. "The TRIPs Agreement Without a Competition Agreement?," presented at the Fondazione Eni Enrico Mattei workshop Trade and Competition in the WTO and Beyond, Venice, Dec. 4-5.

De Melo, Jaime, Marcelo Olarreaga and Wendy Takacs. 1999. "Pricing Policy Under Double Market Power: Madagascar and the international vanilla market," Review of Development Economics, forthcoming.

Djankov, Simeon and Bernard Hoekman. 1998. "Conditions of Competition and Multilateral Surveillance," The World Economy, 21:1109-28.

European Commission. 1995. "Competition policy in the new trade order strengthening international cooperation and rules," Report of the group of experts, July ("Van Miert Report").

European Commission. 1996. "Towards an International Framework of Competition Rules," Communication to Council, Com (96) 284, June 18.

Finger, J. Michael. 1982. "Incorporating the Gains from Trade into Policy," World Economy, 5:367-77.

Finger, J. Michael (ed.). 1993. Antidumping. Ann Arbor: University of Michigan Press.

Fox, Eleanor. 1997. "Toward World Antitrust and Market Access," American Journal of International Law, 91:1-25.

Fox, Eleanor. 1998. "International Antitrust: Against Minimum Rules; For Cosmopolitan Principles," The Antitrust Bulletin, 43:5-20.

Graham, E. and J.D. Richardson, 1997. Global Competition Policies: An Agenda. Washington DC: Institute for International Economics.

Hindley, Brian. 1996. "Competition Law and the WTO: Alternative Structures for Agreement," in Jagdish Bhagwati and Robert Hudec (eds.), Fair Trade and Harmonization. Cambridge: MIT Press.

Hoekman, Bernard. 1997. "Competition Policy and the Global Trading System," The World Economy, 20: $383-406$. 
Hoekman, Bernard and Petros C. Mavroidis. 1994. "Competition, Competition Policy and the GATT," World Economy, 17:121-150.

Hoekman, Bernard and Petros C. Mavroidis. 1996. "Dumping, Antidumping and Antitrust," Journal of World Trade, 30:27-52.

Holmes, Peter. 1996. "Competition Policy and Integration: Leveling or Tilting the Playing Field," Global Economic Institutions Working Paper Series No. 21.

Holmes, P. et al. 1997. "International Competition Policy: the Long March to the WTO," ESRC, mimeo.

Janow, Merit. 1998. "Unilateral and Bilateral Approaches to Competition Policy Drawing on Trade Experience," in R. Lawrence (ed.), Brookings Trade Forum, 1998. Washington DC: Brookings Institution.

Khemani, R. Shyam and Mark Dutz. 1995. "The Instruments of Competition Policy and Their Relevance for Economic Development," in C. Frischtak (ed.) Regulatory Policies and Reform: A Comparative Analysis. Washington D.C.: The World Bank.

Klein, Joel. 1995. "International Antitrust: a Justice Department Perspective", Speech to Fordham Corporate Law Institute, New York City, October 26.

Klein, Joel. 1998. "No Monopoly on Antitrust," Financial Times, February 13, p. 24.

Lloyd, Peter. 1998. "Multilateral Rules for International Competition Law?," The World Economy, 21:1029-49.

Marsden P. 1997. "Dealing with International Exclusion: The Right Focus for the WTO Working Group on Trade and Competition Policy," World Competition.

Maskus, Keith. 1998. "The International Regulation of Intellectual Property," Weltwirtschaftliches Archiv.

Mavroidis, Petros C. and Damien Neven. 1998. "Some Reflections on Extraterritoriality in International Economic Law," mimeo.

OECD. 1998. Recommendation of the Council concerning effective action against hard core cartels. Paris: OECD, May.

Primo Braga, Carlos. 1996.. Trade Related Intellectual Property Issues: the Uruguay Round and its Economic Implications," in W. Martin and L.A. Winters (eds.), The Uruguay Round and the Developing Countries Cambridge: Cambridge University Press.

Richardson, J. David. 1998. "Multilateralizing Conventions," in R. Lawrence (ed.), Brookings Trade Forum, 1998. Washington DC: Brookings Institution.

Roberts, Mark and James Tybout (eds.). 1997. Industrial Evolution in Developing Countries. Oxford: Oxford University Press. 
Scherer, F. M. 1994. Competition Policies for an Integrated World Economy. Washington D.C.: Brookings Institution.

UNCTAD. 1997. World Investment Report. Geneva: UN.

WTO. 1997. Annual Report: Trade and Competition, Geneva: WTO

WTO. 1998a. Working Group on the Interaction between Trade and Competition Policy, Report to the General Council, Dec 8.

WTO. 1998b. "Japan: Measures Affecting Consumer Photographic Film and Paper," Panel Report, March. 

Policy Research Working Paper Series

\begin{tabular}{|c|c|c|c|c|}
\hline & Title & Author & Date & $\begin{array}{l}\text { Conpet } \\
\text { Tor perper }\end{array}$ \\
\hline WPS2187 & $\begin{array}{l}\text { Who Determines Mexican Trade } \\
\text { Policy? }\end{array}$ & $\begin{array}{l}\text { Jean-Marie Grether } \\
\text { Jaime de Melo }\end{array}$ & September 1999 & $\begin{array}{l}\text { L. Tabada } \\
36896\end{array}$ \\
\hline WPS2188 & $\begin{array}{l}\text { Financial Liberalization and the } \\
\text { Capital Account: Thailand, 1988-97 }\end{array}$ & $\begin{array}{l}\text { Pedro Alba } \\
\text { Leonardo Hernandez } \\
\text { Daniela Klingebiel }\end{array}$ & September 1999 & $\begin{array}{l}\text { R. Vo } \\
33722\end{array}$ \\
\hline WPS2189 & $\begin{array}{l}\text { Alternative Frameworks for } \\
\text { Providing Financial Services }\end{array}$ & $\begin{array}{l}\text { Stijn Claessens } \\
\text { Daniela Klingebiel }\end{array}$ & September 1999 & $\begin{array}{l}\text { R. Vo } \\
3372.2\end{array}$ \\
\hline WPS2190 & $\begin{array}{l}\text { The Credit Channel at Work: Lessons } \\
\text { from the Republic of Korea's Financial } \\
\text { Crisis }\end{array}$ & $\begin{array}{l}\text { Giovanni Ferri } \\
\text { Tae Soo Kang }\end{array}$ & September 1999 & $\begin{array}{l}\text { K. Labrie } \\
31001\end{array}$ \\
\hline WPS2191 & $\begin{array}{l}\text { Can No Antitrust Policy Be Better } \\
\text { Than Some Antitrust Policy? }\end{array}$ & Aaditya Mattoo & September 1999 & $\begin{array}{l}\text { L. Tabada } \\
36896\end{array}$ \\
\hline WPS2192 & $\begin{array}{l}\text { Districts, Spillovers, and Government } \\
\text { Overspending }\end{array}$ & Reza Baqir & September 1999 & $\begin{array}{l}\text { S. Devadas } \\
87891\end{array}$ \\
\hline WPS2193 & $\begin{array}{l}\text { Children's Growth and Poverty in } \\
\text { Rural Guatemala }\end{array}$ & Michele Gragnolati & September 1999 & $\begin{array}{l}\text { M. Gragnolat } \\
85287\end{array}$ \\
\hline WPS2194 & $\begin{array}{l}\text { Does Democracy Facilitate the } \\
\text { Economic Transition? An Empirical } \\
\text { Study of Central and Eastern Europe } \\
\text { and the Former Soviet Union }\end{array}$ & $\begin{array}{l}\text { Jean-Jacques Dethier } \\
\text { Hafez Ghanem } \\
\text { Edda Zoli }\end{array}$ & October 1999 & $\begin{array}{l}\text { H. Ginanem } \\
85557\end{array}$ \\
\hline WPS2195 & Aggregating Governance Indicators & $\begin{array}{l}\text { Daniel Kaufmann } \\
\text { Aart Kraay } \\
\text { Pablo Zoido-Lobatón }\end{array}$ & October 1999 & $\begin{array}{l}\text { D. Bouve! } \\
35818\end{array}$ \\
\hline WPS2196 & Governance Matters & $\begin{array}{l}\text { Daniel Kaufmann } \\
\text { Aart Kraay } \\
\text { Pablo Zoido-Lobatón }\end{array}$ & October 1999 & $\begin{array}{l}\text { D. Bouve! } \\
35818\end{array}$ \\
\hline WPS2197 & $\begin{array}{l}\text { Production Sharing in East Asia: } \\
\text { Who Does What for Whom, and Why? }\end{array}$ & $\begin{array}{l}\text { Francis } \mathrm{Ng} \\
\text { Alexander Yeats }\end{array}$ & October 1999 & $\begin{array}{l}\text { L. Tabada } \\
36896\end{array}$ \\
\hline WPS2198 & $\begin{array}{l}\text { How the Chinese System of Charges } \\
\text { and Subsidies Affects Pollution } \\
\text { Control Efforts by China's Top } \\
\text { Industrial Polluters }\end{array}$ & $\begin{array}{l}\text { Hua Wang } \\
\text { Ming Chen }\end{array}$ & October 1999 & $\begin{array}{l}\text { H. Warg } \\
33255\end{array}$ \\
\hline WPS2199 & Managing Risks of Capital Mobility & Mansoor Dailami & October 1999 & $\begin{array}{l}\text { W. Nedrow } \\
31585\end{array}$ \\
\hline WPS2200 & $\begin{array}{l}\text { The Role of Trust in Financial Sector } \\
\text { Development }\end{array}$ & Biagio Bossone & October 1999 & $\begin{array}{l}\text { E. Weknova } \\
85864\end{array}$ \\
\hline
\end{tabular}




\section{Policy Research Working Paper Series}

Titie

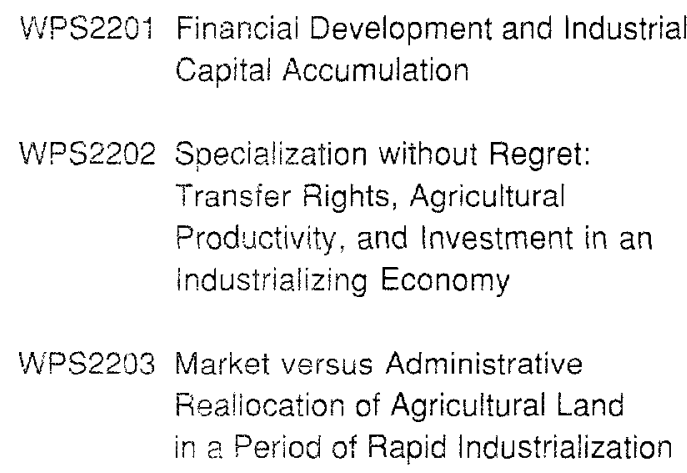

WPS2204 Corruption under Moral Hazard

WPS2205 Foreign-Owned Capital and Endogenous Tariffs

WPS2206 Household Childcare Choices and Women's Work Behavior in Russia

WPS2207 Jamaica's Food Stamp Program: Impacts on Poverty and Welfare

WPS2208 Ethric Partition as a Solution to Ethnic War: An Empirical Critique of the Theoretical Literature

WPS2209 Does Corruption Relieve Foreign Investors of the Burden of Taxes and Capital Controls?

WPS2210 The Sliperry Slope: Explaining the Increase in Extreme Poverty in Urban Brazil, 1976-96
Author

Biagio Bossone

Michael R. Carter

Yang Yao

Michael R. Carter

Yang Yao

Gunnar S. Eskeland

Henrik Thiele

Marcelo Olarreaga

Michael M. Lokshin

Kene Ezemenar

Kalanidhi Subbarao

Nicholas Sambanis

Shang-Jin Wei

Fancisco H. G. Ferreira Ricardo Paes de Barros
October 1999

Contact for paper

October 1999

October 1999

October 1999

M. Fernandez 33766

October 1999

H. Sladovich 37698

October 1999

L. Tabada 36896

October 1999

P. Sader 33902

October 1999

G. Peralta 37405

October 1999

H. Sladovich 37698

H. Sladovich 37698

G. llogon 33732 